Acta Universitatis Wratislaviensis No 3998

Anglica Wratislaviensia LVIII, Wrocław 2020

https://doi.org/10.19195/0301-7966.58.7

\author{
Bartosz Dudek \\ ORCID: 0000-0003-4690-1253 \\ Maria Curie-Skłodowska University in Lublin \\ bartosz.dudek@poczta.umcs.lublin.pl
}

\title{
Conceptualising the Punch Line: An Analysis of Humorous Webcomic Stories with the Help of Blending Theory
}

\begin{abstract}
Although research on humour carried out from a cognitive standpoint is well-established, it has mainly contributed to the study of single-framed cartoons. This paper goes further and offers a cognitive multimodal analysis of so-called webcomics, i.e. sequences of multiple cartoon frames published on the Internet. In general, the analysis makes use of Fauconnier and Turner's (2002) Blending Theory and Groensteen's (2007) semiotic approach to comics. These insights equip us with new tools for analysis, enabling us to find out where the punch lines and incongruities reside, as well as explaining how we are able to conceptualize them.
\end{abstract}

Keywords: punch line, cognitive linguistics, webcomics, multimodality, sequence, comics

\section{Introduction}

Humour, contrary to popular belief, is not an exclusively human trait. Animals have a sense of humour too, although there is at least one important element that separates us. How often do we get to listen to an ape telling a joke? Doing something funny-yes: apes are able to throw their playmates out of a tree just for fun, but creating a funny incident through language is an exclusively human trait. We are the only ones who tell jokes and create fictional situations using our imaginations. No wonder then that the relationship between language and humour has always met with great interest, especially from great authors. George Orwell, for example, says that humour is not only a critical element of our lives which "upsets the established order", but also that it is "a tiny revolution" that helps us to keep a healthy distance from bitter reality. Orwell makes a vital point, stressing the importance of humour as both a critical tool and a remedy. Many studies have shown that hu- 
mour has a positive impact on both our health (e.g. Gremigni 2012) and spirit (e.g. Bolkan, Griffin, and Goodboy 2014); whereas language is a vehicle for delivering humour. There are many visual, linguistic and other ways of conveying humour, which have been repeatedly analyzed in numerous scientific theories of humour (notably Keith-Spiegel 1972; Raskin 1985; Attardo 1994). In view of this research, it is generally accepted that a few crucial steps are necessary in order to achieve a humorous effect, with the punch line being the final one that triggers amusement at the very end of the enunciation. These steps can be portrayed in different forms. When we tell a joke, each proposition is a step further towards a possible resolution. In cartoons and other examples of visual humour, each scene plays a similar role. If all the elements fall into line, and if the punch line is received as intended, we laugh. So far, research on humour has mainly been focusing on single-frame cartoons, but humour is a dynamic process, exploiting punch lines in different ways. It brings us to the question: where do punch lines reside in multi-panel comics, and how do we conceptualize them? To explore these two questions, this article analyzes multi-panel webcomics that represent short, visual, humorous stories. In doing so, use is made of cognitive linguistic tools for analysis, together with Thierry Groensteen's insight into semiotic aspects of comics.

At this point, it is important to stress that our approach is essentially cognitive and the primary question here is where the punch lines reside and how the tools that we use enable us to verify it. For this purpose, the paper splits into several sections. In Section 2, we provide a brief introduction to Blending Theory. Section 3 portrays the conceptual levels of comics and the way we conceptualize them. On the basis of three webcomics, section 4 discusses the way their punch lines are understood in sequence. In the last section we summarise the results of the study.

\section{Conceptual integration and humour}

A highly successful theoretical tool which may explain the way our conceptual system works while understanding a joke is Conceptual Integration Theory (Fauconnier and Turner 2002). It has been repeatedly applied to the analysis of humour and comics, making it a perfect match for our purposes. CIT is based on the idea that humans subconsciously produce meaning through conceptual links (mappings) of meaningful elements residing within mental spaces. Broadly speaking, mental spaces are packets of knowledge that contain salient information available at the moment of conceptualization (Yus 124). When reading a text and trying to understand it, we establish many mental spaces. When we see the word "court" or a picture of this institution, the proper mental space is activated with all the salient information contained within it. This information may include concepts like a judge, a courtroom or a victim. Mental spaces are very often analogically con- 
nected through mappings, which results in the creation of a new mental space called the blend. This newly created mental space contains information that was not present in either of the initial input spaces. In other words, our understanding of the world not only enables us to experience it, but also to make new connections and concepts between the things that we experience. Blended space can be further used as another input space in the ongoing process of constructing meaning. Yet, to establish a connection between mental spaces, they have to meet the condition of having some commonalities between them. We cannot make this connection unless the information that has arisen from our understanding does not share a similar general structure. This general structure is stressed in a so-called generic space.

These elements mark CIT as an influential framework in the analysis of humour in language, since it has been proven that this is also a process during which conceptual relations are being established. Many scholars interested in this subject point to Arthur Koestler as the one who first portrayed how humour converges with the process that CIT accounts for avant la lettre. As he says:

The sudden bisociation of an idea or event with two habitually incompatible matrices will produce a comic effect, provided that the narrative, the semantic pipeline, carries the right kind of emotional tension. When the pipe is punctured, and our expectations are fooled, the now redundant tension gushes out in laughter ... (Koester 51)

Other scholars explain that Koestler's "two incompatible matrices" are mental spaces that create a sort of inconsistency, or incongruity, as we shall call it. One of these theories is the Theory of Incongruity and Release which, according to Dynel, explains the nature and purpose of humour (64). As we can read, through the analysis of verbal, visual or any other information, we instigate the process of resolution. For Dynel, "the interpreter tries to find a cognitive rule rendering the incongruous elements congruous, with a view to arriving at an understanding of the incongruity and the whole stimulus" (ibid.). In CIT terms, incongruity between two or more mental spaces, their selection and the further adoption of relevant elements in the blend, result in the removal of tension (in the form of amusement) accumulated by this inconsistency. In this way, as Orwell said, a joke becomes "a tiny revolution", that is a sudden shift in the way we have been thinking about one concept that is later inverted into something rather unexpected.

To provide an even clearer view of the way conceptual mappings are organized and how the integration between mental spaces results in humorous effect, consider the following joke:

(1) Q: How'd you make God laugh?

A: Tell Him your plans.

How to explain the incongruity of this joke? First, note that incongruity generates tension through its interrogative form, so that we encounter an information gap, which in turn, is a "trigger of wonder" in the aesthetic experience (see Loewenstein 
1994). According to the classical view of verbal humour (Suls 1972), the appreciation of jokes entails "the recognition of incongruity" and "resolution via adoption of another set of assumptions" (Coulson). In our instance, the incongruity results from the blending of two mental spaces that share common structure.

Both mental spaces share mutual elements, such as receivers of the joke (God/ God'), agents (prayer/joke teller), verbal acts (praying/telling jokes) and the like. Such a structure enables us to notice the incongruity between the elements, namely the incongruity arises because of the presumption that we do not customarily tell jokes to God, nor do we want Him to be amused. In order make things congruous and laugh, we need a resolution. The resolution lies in the answer, which fills our expectation gap in an unexpected though fitting way. In this case, on the one hand, we pray to God to ask for the fulfilment of our prayers and plans, and on the other hand, we tell jokes to amuse ourselves. On a blending level, the blend recruits elements from both mental spaces. New information emerges, puncturing, as it were, the balloon of tension which results in us laughing.

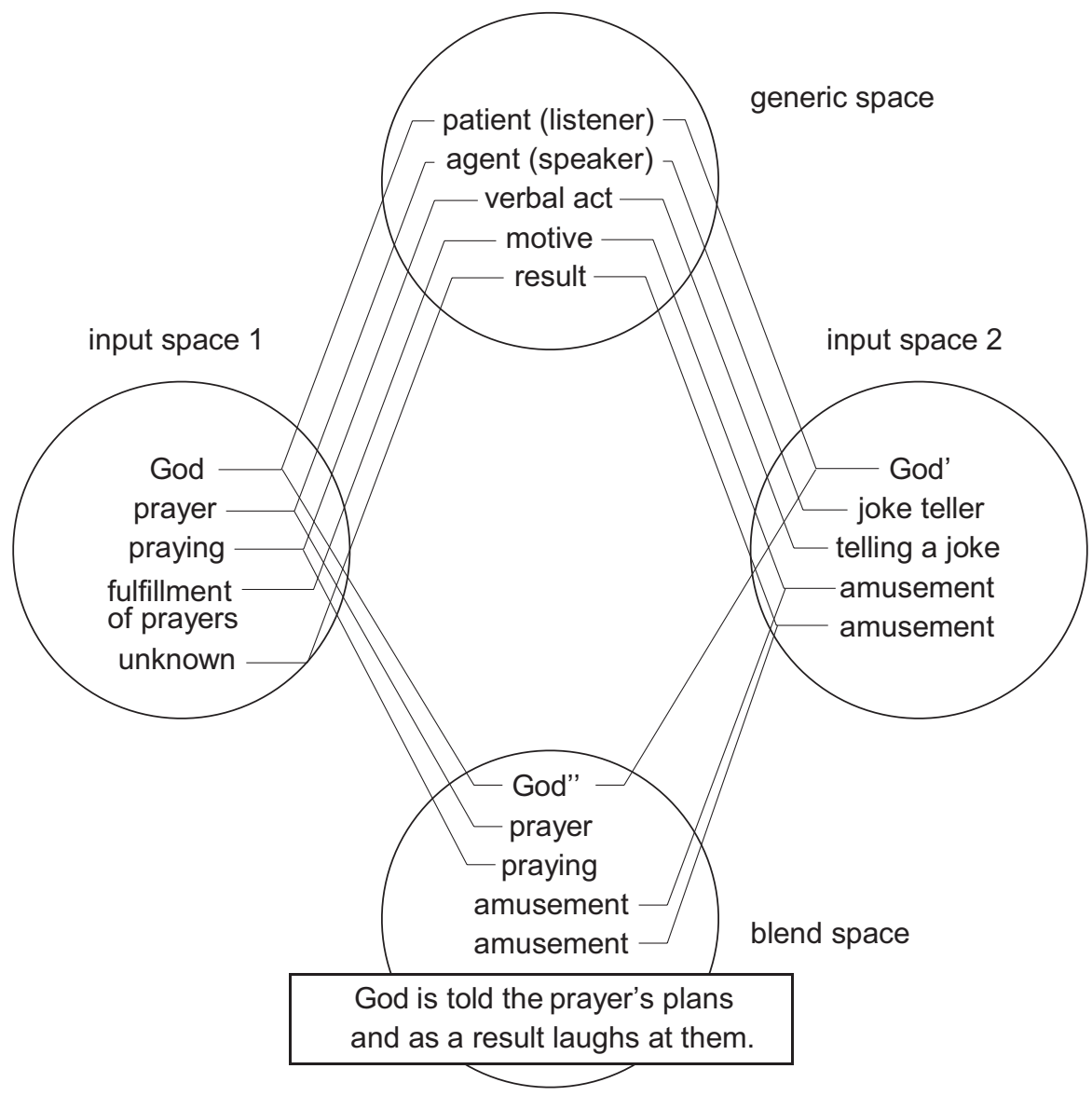

Figure 1: Incongruous mental space integration of (1)

Anglica Wratislaviensia 58, 2020

(C) for this edition by CNS 


\section{The conceptualization of comics}

There are many ways of delivering humour, and CIT allows us to account for most of them. This theory has been applied to many studies of visual humour (e.g. Coulson 2005; Libura 2017), but there is a relative paucity of research into comic strips that portray short amusing stories. In the following part, we will analyze three stories with the help of CIT, but before we embark on this task, a brief characterization of comics and the elements they encompass is in order.

Despite their relatively basic form, comics are something more than simple sets of text and images. For Thierry Groensteen (2007), one of the leading researchers in this field, comics feature diverse forms and they maintain basic characteristics of language that consists of a sequence of images. The sequence, Groensteen argues, is an integral component for meaning construction, which conveys meaning in a similar way to sequences in films. When reading a comic, we select both visual and textual elements of its content and interpret them accordingly (Deleuze 1986). The messages contained in comic panels manifest themselves not only in individual frames, but also as a part of the pre-existing contextual information and specific relations in which they appear. As Groensteen further explains, "for the comics reader, the fact of presupposing that [in a comic sequence] there is a meaning necessarily lead him to search for the way that the panel that he 'reads' is linked to the others, and how it re-reads in light of others" (75; cf. Saraceni 2013). Furthermore, the visuals of comics "do not depict the world through pure analogy or iconicity but are deliberate means of communication, anchored in particular discourse contents and imbued with rhetorical purposes" (Kukkonen 159). Overall, the process of understanding comics is multifaceted. It is strongly influenced by our own beliefs and the discourse we are engaged in while reading.

Taking all of the above into consideration, comics may be understood as employing the language of conjunction and repetition, linking together the content that occurs within their panels. Moreover, the structure of comics conveys humour through the use of an alternative mixture of modes of expression (11), making it truly a special case for analysis. This view on comics is also in agreement with the cognitive standpoint, which defines a succession of scenes as the narrative-a complex network of mental spaces combined in blends (Semino 2009). Put differently, the narrative of comics can be described as a sequential and continual modification of readers' experience in which new reciprocal correlations emerge in the panels, via visual, textual and other channels. While reading comics, one becomes an active participant, negotiating their meaning and arriving at their punch lines.

\section{An analysis of webcomics}

Over the last two decades we have been observing how the number of ways of delivering humour is constantly increasing and developing. This can be partially at- 
tributed to the Internet, which provides publishing freedom together with unlimited access to an unlimited audience. This is how webcomics came into being. Today they feature a wide range of different categories which bring together a number of exclusive communities that share unique sets of collectivist knowledge, making webcomics an even more unique corpora for analysis. We have already established that webcomics share a similar structure to traditional comics, but as Jan-Noël Thon says, although webcomics' semiotic dimension is similar to other media, like newspapers or cartoons, they differ rather significantly with regard to the place and manner in which they are published (17). Draw Liming goes even further, saying that in "some webcomics called one-shots, each strip is a self-contained story (18). Other webcomics are serials, which have long-running plots and regularly occurring characters". Thus, the difference between traditional comics and webcomics becomes evident if one compares the way they are published and produced, but not the way we conceptualize them.

There are some more explicit differences, however. Whereas traditional comics tell stories across many episodes in which humour is occasional, webcomics are often short and feature heightened expectations for humour, since many of their stories are specifically designed to amuse. Humour in webcomics, moreover, is easily accessible, and that is precisely the reason why they are the right kind of medium for our purpose. Still, in approaching these matters, we ignore differences other than semiotic ones between comics and webcomics; our concern is rather with the phenomenon that emerges from the conceptualization of consecutive panels, ultimately leading to a humorous effect. This concern is addressed in the following cases.

The first one refers to a Biblical episode from The Book of John. It tells the story of a woman caught in adultery who is brought before Jesus. The Scribes and Pharisees claim that the woman was caught cheating on her husband. The punishment for such a crime, according to Mosaic Law, was death by stoning (Authorized King James Bible, Deut. 22.22-24). Christ, being aware that an intrigue is being plotted against him, famously says: "He that is without sin among you, let him cast the first stone at her" (Authorized King James Bible, John 8.7). As a result, Jesus saves the woman's life and also disentangles himself from the intrigue.

A similar story is depicted in Conor Ullmann's two-panel webcomic (figure 2). Here, the blend of Jesus' culturally-rooted message of self-awareness and forgiveness with visual and textual elements is established. The first panel of the webcomic presents Jesus, who introduces himself so that there is no other possible interpretation of who he could be. Jesus also gives a speech in defence of the scared character beside him. In comparison to the speech from the parable, the one in the webcomic is modified, omitting a direct reference to the crowd. In the second panel the plot unfolds in a surprising way. Jesus is the one who casts the stone at the victim who he has just been defending.

To conceptualize and interpret the story, the elements of the first panel create a diegetic world that draws on the reader's knowledge of the parable and on what he 


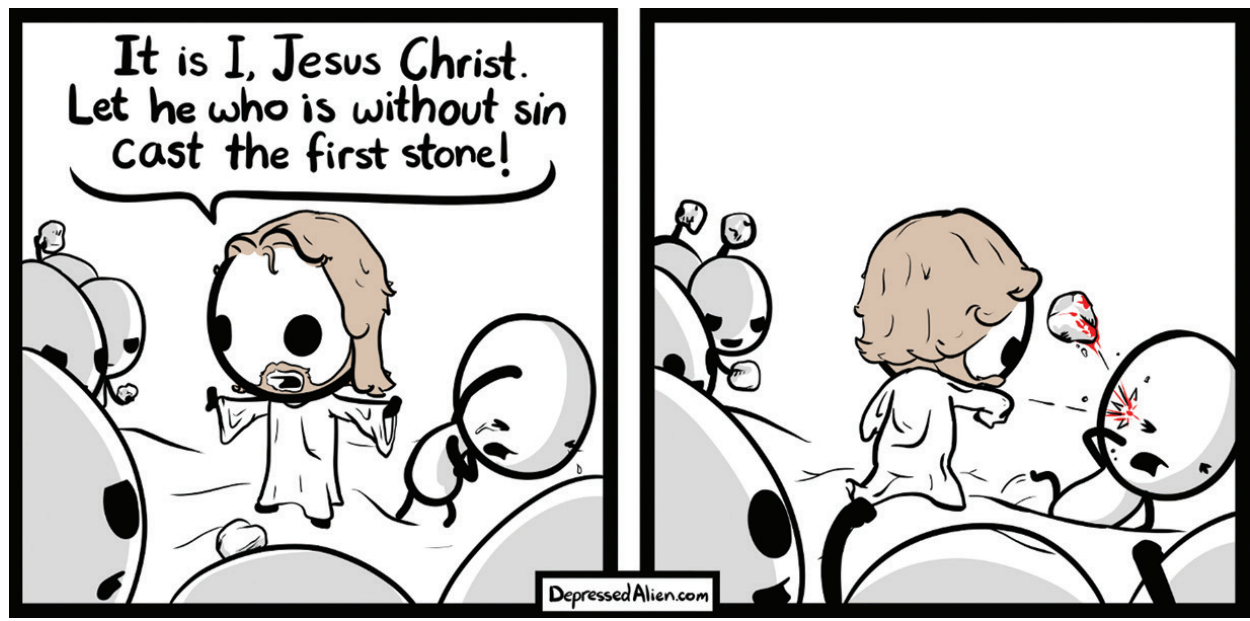

Figure 2: Being without sin from Depressed Alien by Connor Ullmann

Source: retrieved from http://www.depressedalien.com/321. 1 Jul. 2019.

is currently experiencing. Additionally, please recall that, for most Christians, Jesus of Nazareth is the incarnation of God, the Son and Messiah, and that his cultural model, especially within these religious circles, portrays him as a divinity that has unsullied character without any limitations or imperfections (McGrath 4-6). The parable itself symbolises Christ as a merciful master who urges us to take a look within ourselves before condemning anyone else. This knowledge is supposed to activate the following two mental spaces that share a similar structure (figure 3). Conceptual links are omitted due to the clarity of the reading.

In the second panel, somewhat against this model, and against what we know about the parable from the Bible, Jesus takes his own words literally and casts the first stone. This is the moment for incongruity to arise, where both visual and textual inputs from one space and cultural inputs from another become incompatible. The blend recruits the elements from both input spaces and lays the foundation for further correlations, creating a hyperblend - a blend that serves as an input space to another blend (Turner 23). The first blend represents the compressed relation between our knowledge about the parable and the visual input of the first panel. In the second panel, separated by closure and the separative functions of the frame, ${ }^{1}$ feature input spaces 3 and 4 , which in consequence of their mutual relations, prompt the reader to create a second blended space that leads to an incongruous state. The reason for this is the non-fulfilment of our expectations. We expected that Jesus will

${ }^{1}$ Closure and the separative functions of the frames impact the meaning of comic panels. The first one closes or circumscribes a given panel and the diegetic fragment of the story attached to it. The second function marks off panels and also the continuum of a story. For more functions of the frames see Groensteen (28-39). 
FRAME $1 \quad$ generic space 1

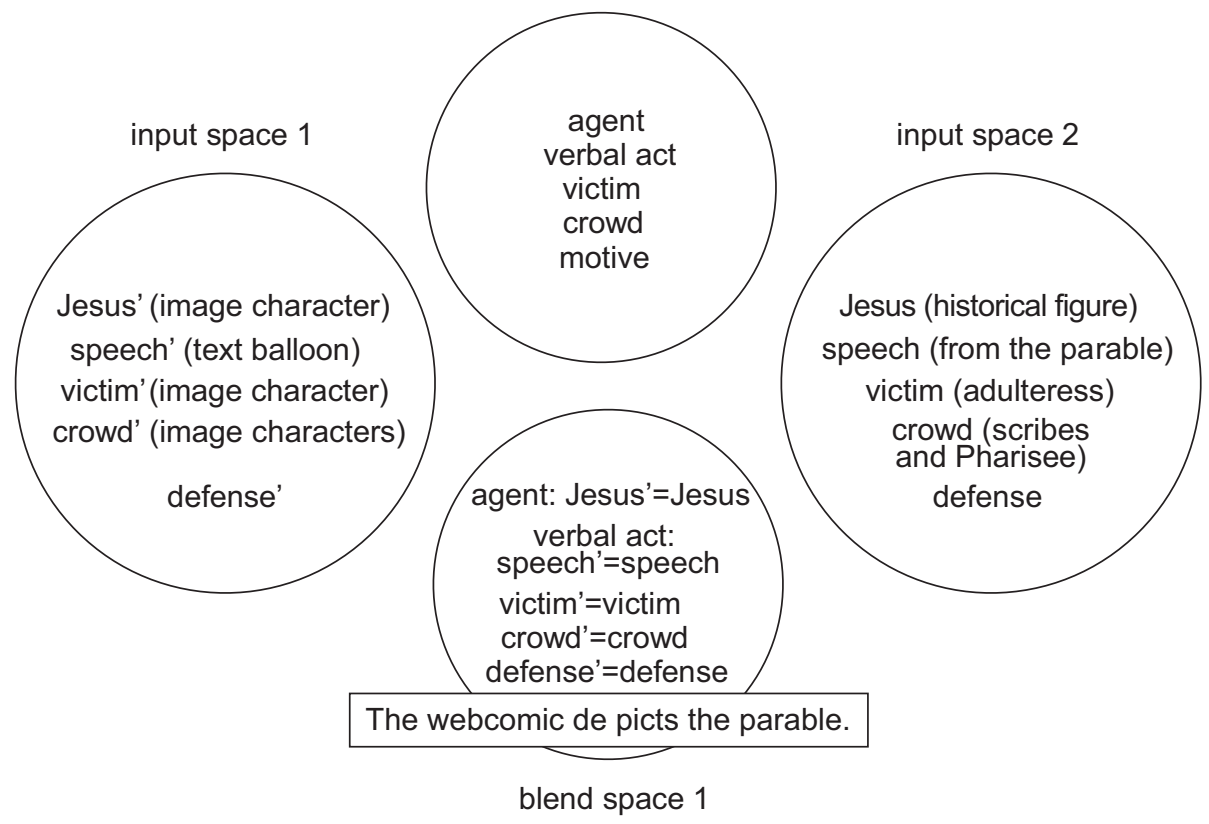

FRAME 2 generic space 2

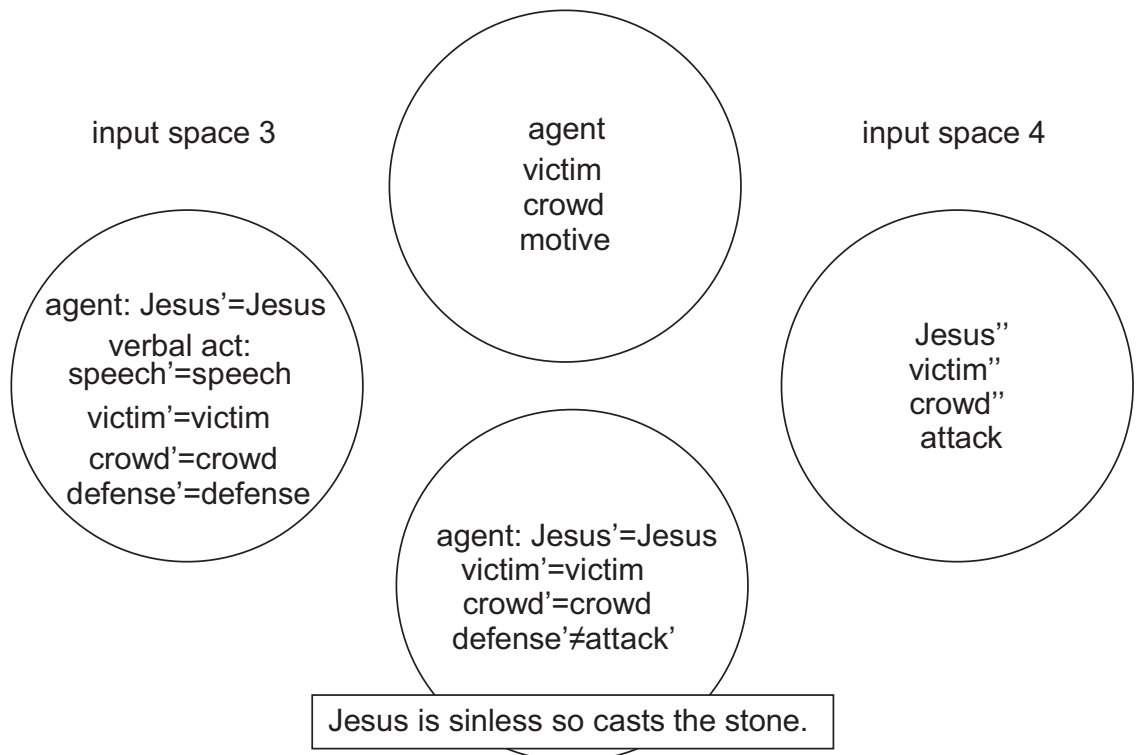

blend space 2

Figure 3: The set of possible conceptual relations of figure 2 
try to defend the victim, but it is quickly violated because of the second blended space. The punch line of this story, moreover, is of implicit character and does not belong to the diegetic world. It can, nevertheless, be inferred through the adoption of another set of available assumptions. If this is the case, we could assume that Jesus takes his own words literally, and as a sinless man casts the first stone.

The second webcomic drawn by Ullmann is a two-panel portrayal of a courtroom. It is commonly known that the court, in order to bring justice on the basis of proof and facts, is an institution pursuing alleged violations of the law. A court is also a place of tradition and formality, so that all participants at trials, and especially the administrative body, are obliged to follow court procedures and customs, such as wearing an appropriate style of clothing or behaving in a formal way. The webcomic portrays a judge who says, “...The court finds the defendant guilty because he totally looks like he did it", and confirms the judgement by tapping with his gavel. The second part somewhat cinematically zooms out from the first panel and shows the front of the court building. Above the court hangs a sign saying "the COURT of PUBLIC OPINION".

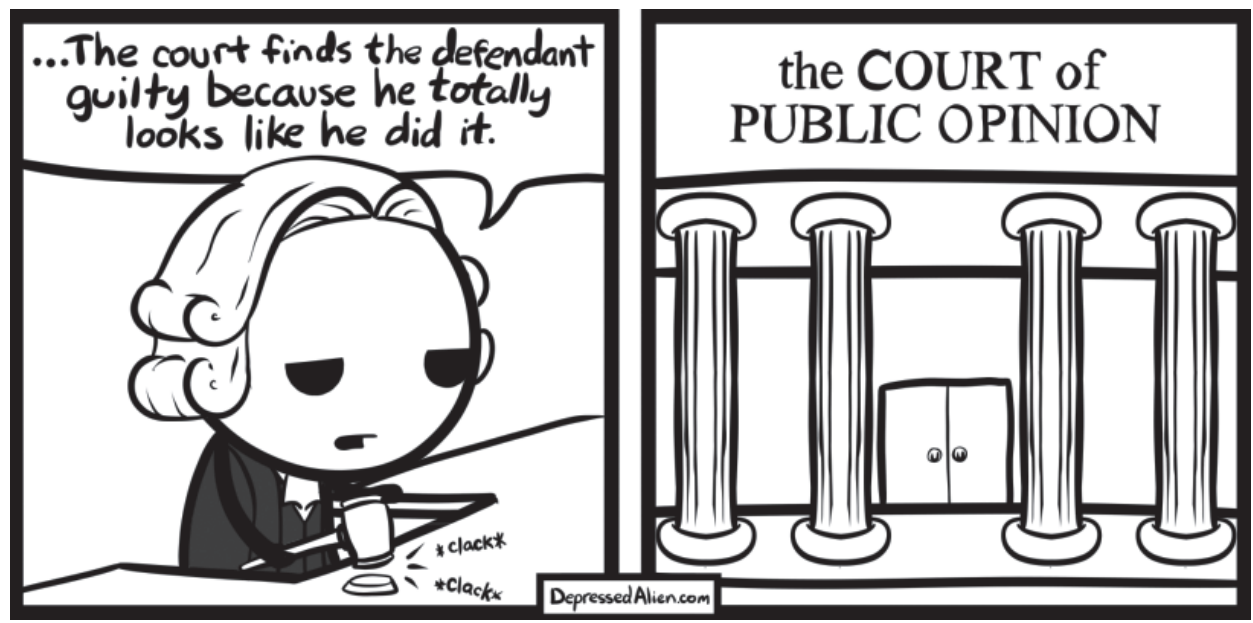

Figure 4: The Court of Public Opinion from Depressed Alien by Connor Ullmann

Source: retrieved from http://www.depressedalien.com/196. 1 Jul. 2019.

Against our common knowledge of the court, the judge from the webcomic uses colloquial language. Moreover, the judge bases his decision on the outward appearance of the defendant, which is commonly considered to be an unsound prejudgement, inadequate to the rule of law that is supposed to be founded on valid proof of facts (Lawrence). The second frame depicts the whole situation by referring to the concept of "the court of public opinion". Wallace Campbell notes that it is "commonly supposed that courts, juries, and counsel constitute the proper tribunal ordained by the people for the trial of alleged criminals" (103). However, in the case 


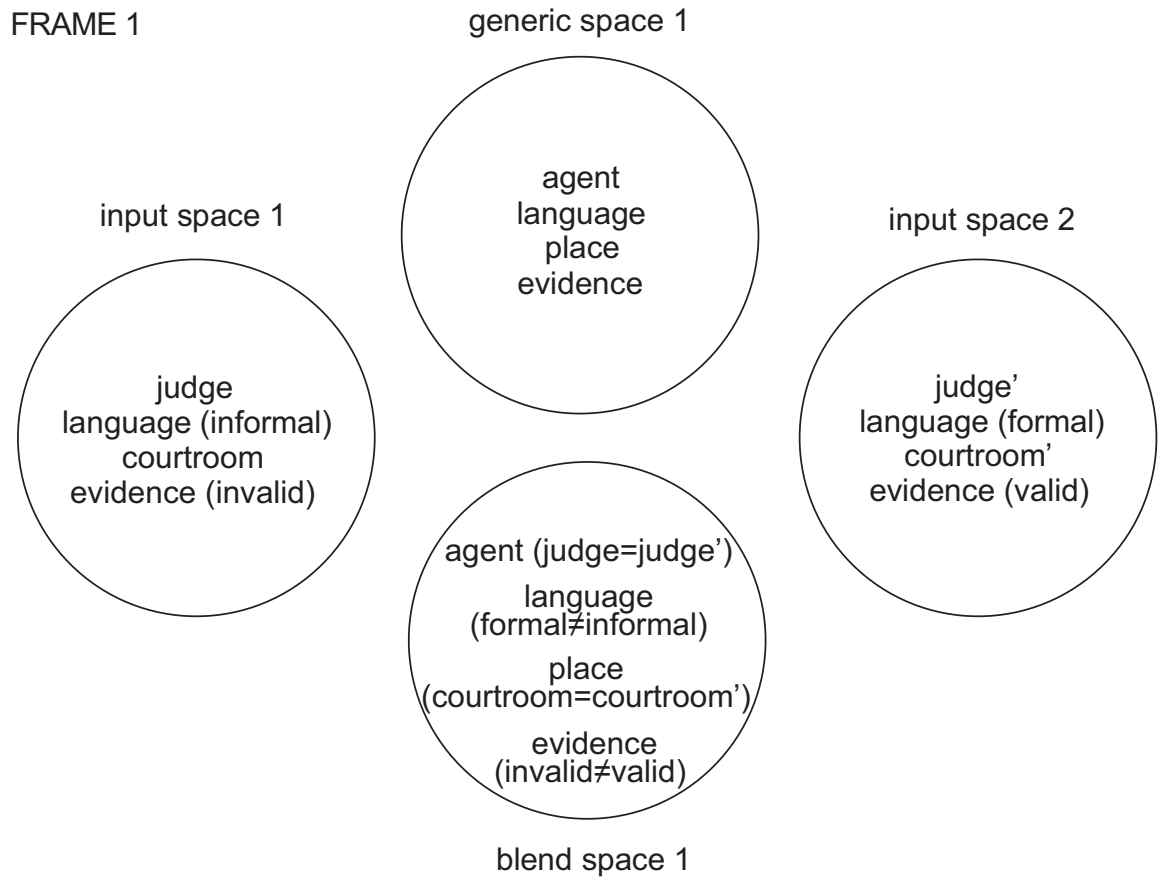

FRAME 2

generic space 2

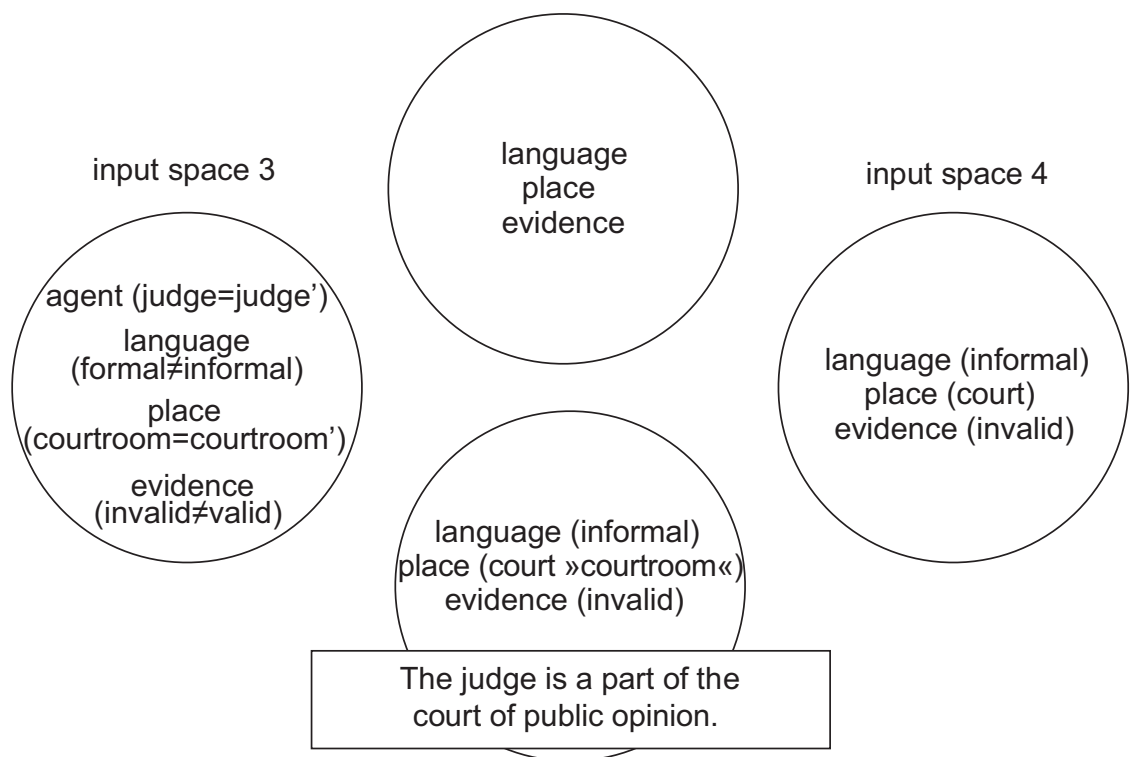

blend space 2

Figure 5: A set of possible conceptual relations of figure 4 
of the court of public opinion, that is a trial in which mass media or similar bodies shift public support to one or another side in a court case, "the machinery of justice exists merely for the purpose of automatically registering the prejudiced decision of a self-constituted tribunal". In such cases, the defendant, even before being convicted, may be ostracized by public opinion and his reputation tarnished. For these reasons, Ullmann's webcomic strip is not a case of language etiquette failure, as the first panel suggests. The point of the webcomic is that if court decisions were left to the public, they would be characterized by bias, injustice and prejudgement.

The punch line involves the judge's informal use of language in the courtroom and the subjectivity of public opinion. As we know, judges are people who exercise significant governmental power and are regarded as a high authority and legally educated individuals with a strong moral character. Thus, the language used by such people is supposed to be legally and technically impeccable. In the first panel, however, the colloquial use of language marks a bizarre deviation from the norm, creating an incongruity that has to be resolved. The solution can be found in the next panel, where there is information about the court of public opinion which symbolizes apparent prejudgement and which has nothing in common with the official institution of the court. This new set of available assumptions is adopted by the reader, re-framing the judge as a representative of a different kind of judicial institution for whom objective evidence is unnecessary, prejudice is unnoticed, and the use of informal language is appropriate.

The last webcomic is more explicit. It is from Karl Zorowski's series entitled Church Mice. It is a dialogue between two mice, where the first one starts by marking the relationship between God and its mother. The story takes place across three consecutive panels that are interrelated via the text balloon. The case in which a dialogue balloon passes through other configurations is called inset or incrustation. As Groensteen explains, inset plays one of two roles in comics. It "serves the purpose of the picture when it magnifies the background panel", or it "serves the story when its purpose is the contextualization of the inset panel" (59-60). In our case, the second panel text balloon interacts with the neighbouring ones, triggering continuous discourse and dictating a more semantic articulation of the story. The second text balloon violates the separative and closing functions of the frames, so that the whole webcomic, although divided into three parts, can be read as a single undivided continuum, as a dialogue of sorts, but still its contents are noticeably separated.

The second balloon presents not only the preacher mouse acknowledging the analogy between the mouse's mother and God, but also providing its own interpretation of what it could mean. The mouse explains it by saying that a "mother's love for her child is one of the most precious things". As the story unfolds, the first mouse provides its own understanding of this analogy, re-framing it in an unexpected way. The whole webcomic revolves around the archetype of mothers and the Christian God (Jung 38-41). Therefore, the very first clue the preacher mouse arrives at are the traits that God is believed to possess. This belief, among other sources, 


\section{Churech mice}

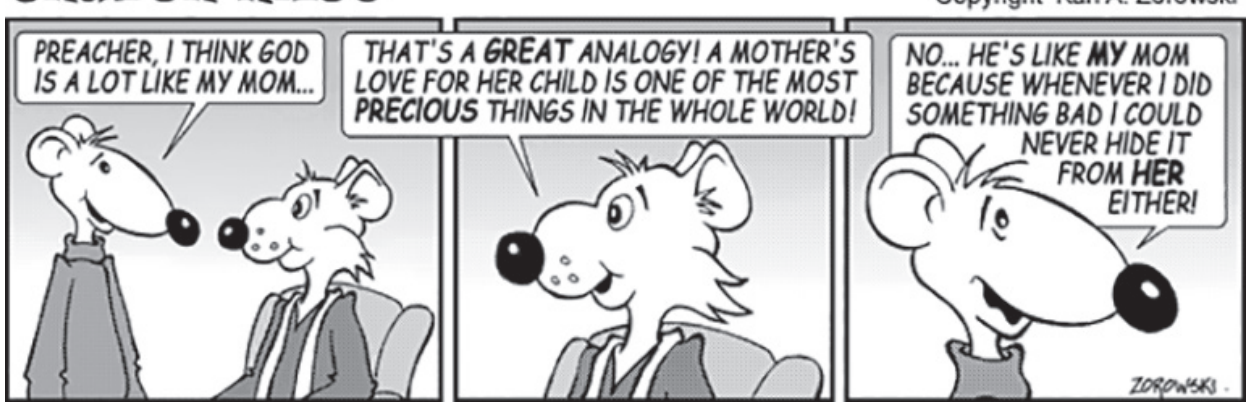

Figure 6: Canonization from Church Mice by Karl Zorowski

Source: retrieved from https://churchmice.net/?page_id=415. 1 Jul. 2019.

may come from the Bible, which says that "love is of God" and "For if our heart condemns us, God is greater than our heart, and knoweth all things" (Authorised King James Bible, 1 John 4.7, 3.20). The preacher also evokes the mother archetype, implicitly referring to the Virgin Mary, since as Jung says, "the historical example of the dual nature of the mother most familiar to us [is] in the Virgin Mary, who is not only the Lord's mother, but also, according to the medieval allegories, his cross" (82). This assumption is easily accessible to the preacher mouse. The duality mentioned by Jung also plays a role in the following part of the dialogue. Please recall that mothers are strongly associated with parental love and the unity between them and their children too. In the third panel, however, the mouse negates ${ }^{2}$ this positive image, and explicitly points to another set of available, but less probable assumptions. It brings the negative nature of God to our attention and mothers as those from whom no one can hide anything. This scenario is portrayed in figure 7. The generic spaces are omitted due to the clarity of reading.

Due to the inset and the use of ellipsis, ${ }^{3}$ the blend takes place across three overlapping frames and involves analogical connections ${ }^{4}$ between mental spaces, with all their essential facets evoked. As a result, the concept of God is metaphorically understood in terms of the concept of mother. The negation of positive traits gives rise to an incongruity which is later resolved by the explicit and unexpected

${ }^{2}$ In cognitive studies, negation is understood as "a function that takes a single argument, which refers to a set of models of possibilities, and returns the complement of the set." In other words, it excludes an already existing assumption and replaces it with a new one (Khemlani, Orenes, and Johnson-Laird 2012). Moreover, Hidalgo-Downing argues that negation often correlates with humorous effect, and it can be treated as "schema refreshment [which] contributes to the challenging of a reader's schemata during the process of comprehension" (138).

3 It may signify, for example, an interruption or a moment for reflection (McShane 2005).

${ }^{4}$ Such relations, as Fauconnier and Turner explain, are easily accessible and do not create a blended space, since there is no new information that could emerge $(19,35)$. 
FRAME 1

FRAME 2

FRAME 3

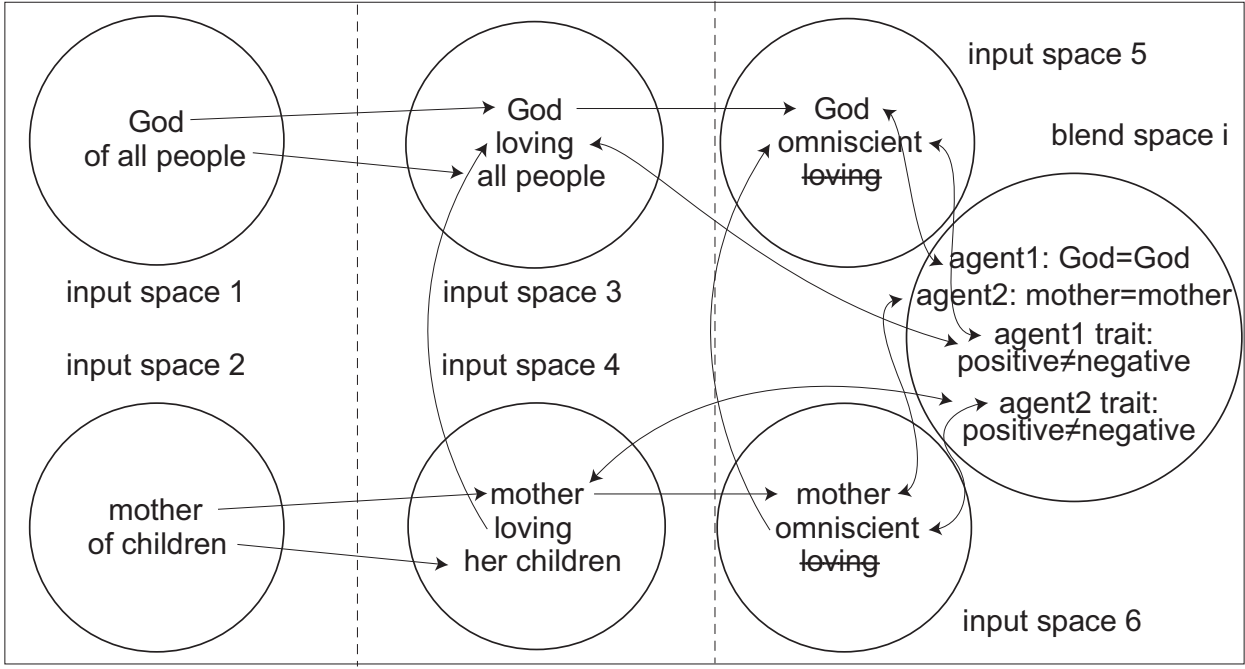

Figure 7: A set of possible conceptual relations of figure 6

assertion portraying the mouse's mother and God as fearsome adversaries rather than close supporters. Nevertheless, although the mouse provides us with this assertion explicitly, the punch line of the joke is implicit, since one has to know that God, similarly to mothers, is an omniscient creature.

\section{Conclusions}

Webcomic stories are mixtures of incongruous conceptual elements that make use of our knowledge and experience. These conceptual elements are activated through visual and textual input, so that the challenge is to adopt an appropriate set of available information that can be exchanged with a congruous explanation of the stories. In order to do that, we integrate the available information provided across consecutive panels, detect some inadequacies and then re-frame our initial interpretation by unpacking the blend. The whole process allows us to examine our own conceptual system and the knowledge we possess in order to understand the punch lines.

As we hope to have shown, textual and visual information strongly interact with one another. Conceptual mappings, which are routinely exploited, reinforce specific information and enable us to find an outlet for the tension accumulated by incongruity. Our analysis has shown that incongruity may arise at any point, that is at the end (as in the first case and third case), or at the beginning (as in the second case). Incongruity may also be received in a variety of ways. In Ullmann's webcomics it arises through an implicit juxtaposition of two closely associated panels 
and rather marginal textual input. In Zorowski's work, incongruity is a matter of the explicit negation of previous frames.

Another thing is that the way incongruity arises noticeably impacts the further understanding of webcomic punch lines. In the first example, the punch line is of an implicit character, since it makes us backtrack on our already existing assumptions, ultimately forcing us to re-frame Jesus' words as explicit. In the second webcomic, the punch line is in the second panel, so that we are provided with additional visual and textual input that enables us to interpret it accordingly. In contrast, the third punch line is a more explicit case. Here, most of the necessary elements are given in the form of textual balloons, refreshing rather than violating the established order of the analogical connections between the image of a loving mother and God. It seems to be Zorowski's purposeful intention to draw an overlapping balloon as a means of accelerating the narration and underscoring its character. In the result the webcomic does not allow us to conceptualize it right away. Instead, it forces us to follow the story up to the point where it finally surprises us with completely new information.

To further the study of comics, webcomics and any other body of data related to the same semiotic dimension, it is necessary to point out a few observations from our analysis. First of all, webcomics produced by many committed producers and their multi-cultural and age-diverse audience make a great foundation for further empirical discussion on humor and the way it is delivered. Secondly, there are a large number of subsequent webcomic publications on the Internet, some of which date back to the 1980s and may prove useful in conducting a more elaborate analysis. Thirdly, each webcomic producer makes use of various meaning-making mechanisms that may impact the final interpretation. The analysis of such a body of knowledge may turn out to be fruitful in many ways and for many purposes. Finally, as we have observed, both cognitive and semiotic tools prove useful for analyzing comics, opening new doors for their interpretation.

\section{References}

Attardo, S. 1994. Linguistic Theories of Humor. New York: Mouton de Gruyter.

Bolkan, S., D. Griffin and A. Goodboy. 2018. "Humor in the classroom: the effects of integrated humor on student learning." Communication Education. 67.2. 144-64. doi: 10.1080/03634523.2017.1413199. 1 Jul. 2019.

Campbell, W. F. 1887. “The Court of Public Opinion.” The North American Review. 368. 103. Retrieved from https://www-1jstor-1org-1000834dh049e.han.bg.umcs.edu.pl/stable/25101267. 1 Jul. 2019.

Coulson, S. 2005. "What's so funny? Cognitive semantics and jokes." Cognitive Psychopathology/ Psciopatologia cognitive 2.3. 67-78.

Deleuze, G. 1986. The movement-image. Trans. Tomlinson, H. and B. Habberjam. Minneapolis: $\mathrm{U}$ of Minnesota.

Downing, L. H. 2000. "Negation, Text Worlds, and Discourse: The Pragmatics of Fiction." Advances in Discourse Processes. Vol. LXVI. Stamford: Ablex PC. 
Dynel, M. 2011. "Blending the incongruity-resolution model and the conceptual integration theory: The case of blends in pictorial advertising." International Review of Pragmatics 3. 59-83. doi: 10.1163/187731011X561009. 1 Jul. 2019.

Fauconnier, G. and T. Mark. 2002. The Way We Think. Conceptual Blending and the Mind's Hidden Complexities. New York: Basic Books.

Gremigni, P. 2012. Humour and Health Promotion. New York: Nova Science.

Groensteen, T. 2007. The System of Comics. Trans. Beaty, B. and N. Nguyen. Mississippi: UP of Mississippi.

Jung, C. G. 1969. "Archetypes of the collective unconscious.” In: Adler, G. and R. F. C. Hull (eds.). Collected Works of C. G. Jung. Vol. 9. Part 1. Archetypes and the Collective Unconscious. Princeton UP. Retrieved from http://www.jstor.org/stable/j.ctt5hhrnk. 1 Jul. 2019.

Keith-Spiegel, P. 1972. "Early conception of humor: varieties and issues.” In: Goldstein, J. and P. McGhee (eds.). The Psychology of Humor. New York: Academic P, 3-39. doi: 10.1016/B978-012-288950-9.50007-9. 1 Jul. 2019.

Khemlani, S., I. Orenes and N. P. Johnson-Laird. 2012. "Negation: A theory of its meaning, representation, and use." Journal of Cognitive Psychology 24. 541-59. doi: 10.1080/20445911.2012.660913. 1 Jul. 2019.

Koestler, A. 1964. The Act of Creation. London: Hutchinson.

Kukkonen, K. 2013. "Navigating infinite earths". In: Hatfield C., J. Heer and K. Worcester (eds.). The Superhero Reader. Jackson: UP of Mississippi, 155-69.

Lawrence, M. F. 2005. A History of American Law. New York: Touchstone.

Libura, A. 2017. "Conceptual integration and humor.” In: Chłopicki, W. and D. Brzozowska (eds.). Humorous Discourse. Berlin: De Gruyter Mouton, 53-73.

Liming, D. 2012. "Bloggers and webcomic artists: Careers in online creativity." Occupational Outlook Quarterly. 53. 3. Retrieved from U.S. Bureau of Labor Statistics. https://www.bls.gov/ careeroutlook/2012/fall/fall2012ooq.pdf. 1 Jul. 2019.

Loewenstein, G. 1994. "The Psychology of Curiosity: A Review and Reinterpretation." Psychological Bulletin. 116.1. 75-98. doi: 10.1037/0033-2909.116.1.75. 1 Jul. 2019.

McGrath, A. E. 2006. Christianity: An Introduction. Oxford: Blackwell.

McShane, M. J. 2005. A Theory of Ellipsis. Oxford: Oxford UP.

Orwell, G. 1971. "Politics and English Language." In: Orwell, S. and I. Angus (eds.). The Collected Essays, Journalism and Letters of George Orwell. Vol. IV. In Front of Your Nose 1945-1950. London: The Camelot P, 127-40.

Raskin, V. 1985. Semantic Mechanisms of Humour. Dordrecht: D. Reidel.

Saraceni, M. 2013. "Aspects of Textual Connectivity in Comics." In: Cohn, N. (ed.). The Visual Narrative Reader. London: Bloomsbury, 115-26.

Semino, E. 2009. “Text worlds.” In: Brone, G. and J. Vandaele (eds.). Cognitive poetics: Goals, gains and gaps. Berlin: Mouton de Gruyter, 33-37.

Suls, J. 1972. "A two-stage model for the appreciation of jokes and cartoons: An information processing analysis." In: Goldstein, J. and P. McGhee (eds.). The Psychology of Humor. New York: Academic P, 81-100. doi: 10.1016/B978-0-12-288950-9.50010-9. 1 Jul. 2019.

Thon, J. N. 2016. Transmedial Narratology and Contemporary Media Culture. Lincoln: U of Nebraska $P$.

Turner, M. 2006. "Compression and Representation." Language and Literature. 15.1. 17-27.

Yus, F. 2016. Humour and Relevance. Amsterdam: John Benjamins PC. 